\title{
Head lettuce production and nutrition in relation to nutrient solution flow
}

\author{
Cleiton Dalastra ${ }^{1} \mathbb{D}$; Marcelo CM Teixeira Filho ${ }^{1 *} \mathbb{D}$; Marcelo R da Silva ${ }^{1} \mathbb{D}$; Thiago AR Nogueira ${ }^{1} \mathbb{D}$; \\ Guilherme Carlos Fernandes ${ }^{1} \mathbb{D}$
}

${ }^{1}$ Universidade Estadual Paulista (UNESP), Ilha Solteira-SP, Brasil; sauems@gmail.com; mcm.teixeira-filho@unesp.br (*author for correspondence); mrsilva@adm.feis.unesp.br; tar.nogueira@unesp.br; guilherme.carlos.fernandes@gmail.com

\begin{abstract}
The optimum flow rate of nutrient solution in hydroponic system can better nourish the crops, allowing healthy and faster growth of lettuce. However, flow also interferes with electric power consumption, so further researches are necessary, mainly on the effect of flow rate, nutrient accumulation and lettuce production. In this context, the aim of this study was to evaluate nutrition and production of head lettuce in relation to the nutrient solution flow in NFT hydroponic system. The treatments consisted of nutrient solution application at the flow rates $0.5 ; 1 ; 2$, and 4 liters per minute in each cultivation channel. Five replicates per treatment consisted of 15 plants each. The flow in hydroponic systems to produce head lettuce alters the technical performance of the crop. Due to the greater nutrient accumulation in shoot and use efficiency of these elements, the highest production ( $\mathrm{g} / \mathrm{plant}$ ) of head lettuce was obtained with a flow rate of $1 \mathrm{~L} / \mathrm{min}$ of the nutrient solution.
\end{abstract}

Keywords: Lactuca sativa, foliar nutrients contents, foliar diagnosis, nutrient accumulation, NFT hydroponic system.

\section{RESUMO}

Produção e nutrição da alface americana em função da vazão da solução nutritiva

A vazão ótima da solução nutritiva no sistema hidropônico pode nutrir melhor as plantas, possibilitando maior e mais rápido crescimento da alface. Entretanto, a vazão também interfere no consumo de energia elétrica, por isso são necessárias mais pesquisas, principalmente sobre o efeito da taxa de fluxo (vazão), no acúmulo de nutrientes e produção de alface americana. Diante do exposto, objetivou-se com esta pesquisa, estudar a nutrição e a produção de alface americana em função da vazão da solução nutritiva em sistema hidropônico NFT. Os tratamentos utilizados constaram da aplicação de solução nutritiva nas vazões de 0,$5 ; 1 ; 2$ e 4 litros por minuto ( $\mathrm{L} / \mathrm{min}$ ) em cada canal de cultivo. Cada tratamento possuiu cinco repetições, compostas por 15 plantas cada. A vazão em sistemas hidropônicos para produção de alface americana altera o desempenho técnico da cultura. Devido ao maior acúmulo de nutrientes na parte aérea e eficiência de utilização destes elementos, a maior produção (g/planta) de alface americana é obtida com a vazão da solução nutritiva de $1 \mathrm{~L} / \mathrm{min}$.

Palavras-chave: Lactuca sativa, teores de nutrientes foliar, diagnose foliar, acúmulo de nutrientes, sistema hidropônico NFT.

Received on January 15, 2019; accepted on November 20, 2019

L ettuce is the most widely-consumed leafy vegetable in Brazil, since it can be produced all year long, culinary characteristics and cultural acceptance (Abcsem, 2017). Its production totaled over 288 million reais in 2016 , in wholesale market, reaching 105 thousand $t$ (Conab, 2017). In retail market, the production had probably reached 8 billion reais, over 1.5 million $\mathrm{t}$ (Abcsem, 2017). Soil cultivation of this vegetable uses $48 \%$ of its production cost associated with labor (Abcsem, 2017), progressively making room for hydroponic cultivation, seems to be the best alternative due to substantial cost reduction and best added value.
Only in São Paulo State, hydroponic production corresponds to $5 \%$ of total commercialized, at a $280 \%$ market value superior to the conventional (Conab, 2017).

Lettuce is the most expressive species grown in soilless cultivation system, possibly because it is the most popular leafy vegetable, for its short life cycle, high productivity and quick return on invested capital (Londero \& Aita, 2000; Santos, 2000; Gualberto et al., 2009). Additionally, in hydroponic lettuce cultivation, plants generally show better quality and sharp reduction in diseases and pests and are also suitable for a uniform production, resulting in high quality and productivity, as well as, efficient use of water and agricultural inputs (Helbel Junior et al., 2008).

Nutrient Film Technique (NFT, Laminar Nutrient Flow Technique) is characterized by the application and circulation of nutrient solution in cultivation channel among plant roots, with frequency and shifts already programmed (Cooper, 1996). NFT is a closed hydroponical system in which the nutrient solution is pumped from one reservoir and passes through the plant roots in bench channels and then returns to the reservoir by gravity (Faquin \& Furlani, 1999; Santos, 2000; Helbel Júnior, 2004). In this system, plant roots 
are partially immersed in the solution nutrient flow, which is not supposed to flood the whole plant: approximately $2 / 3$ of the roots must be submerged to absorb water and nutrients and $1 / 3$ should be remained non-submerged in order to absorb oxygen (Staff, 1998). However, only the accumulated solution in the reservoir may not have sufficient oxygen concentration $\left(\mathrm{O}_{2}\right)$ and need dilution, to permit the roots, of non-aquatic species such as lettuce to breath properly. Thus, the circulation of the solution under turbulent regime plays an essential role in fluid oxygenation (Carmelo,1996), considering that $\mathrm{O}_{2}$ distribution is not uniform in the solution passing through the channels. Therefore, the greater the turbulent area and the amount of water involved in the movement, the better the gas exchange will be $\left(\mathrm{O}_{2}\right.$ entry into solution and $\mathrm{CO}_{2}$ outlet to atmosphere).

Hydroponics technique requires appropriate as well as constant nutrient supply in order to obtain satisfactory productivities. The amount of nutrients absorbed by lettuce follows the decreasing order $\mathrm{K}>$ $\mathrm{N}>\mathrm{Ca}>\mathrm{P}>\mathrm{Mg}>\mathrm{S}>\mathrm{Fe}>\mathrm{Zn}>\mathrm{Mn}>\mathrm{B}>\mathrm{Cu}$ (Faquin et al., 1996). Conversely, little is known about the influence of nutrient solution flow of hydroponic system on the nutritional state of lettuce. Such information is extremely important, since the flow is responsible for nutrient, water and oxygen conduction to the crop, which normally has no aquatic adaptation (Rodrigues, 2002). Therefore, the ideal nutrient flow rate will be able to feed the plants better, allowing greater and faster growing of the lettuce. Nevertheless, flow also interferes in electrical energy consumption of the hydroponics system, that is the reason why further studies, mainly, on flow rate effect which in most systems ranges from 1.5 to 2.0 liters per minute are necessary to help out producers to cultivate head lettuce. Given the above, the aim of this study was to evaluate nutrition and production of head lettuce in relation to the nutrient solution flow in a hydroponics system NFT.

\section{MATERIAL AND METHODS}

The experiment was carried out at a commercial facility covered with red screen with $25 \%$ shading, in the municipality of Aparecida do TaboadoMS (20³'58'S, 51 $\left.{ }^{\circ} 10^{\prime} 54^{\prime \prime} \mathrm{W}\right)$ from April to May, 2017. Temperature during the experiment ranged from 17 to $24^{\circ} \mathrm{C}$ and relative humidity from 60 to $93 \%$.

The experimental design was completely randomized, with five replicates. Treatments consisted of four nutrient solution flows: $0.5 ; 1.0 ; 2.0$ and 4.0 liters per minute in each cultivation channel. We used 20 experimental plots with 15 lettuce plants per plot.

Experimental units were installed on 7-meter individual benches, bench slope of $10 \%$. Cultivation channels were installed in rectangular section PVC profile, $8-\mathrm{cm}$ width and $4-\mathrm{cm}$ height, perforated at the top, every $25 \mathrm{~cm}$, for the plants. Each bench consisted of seven cultivation channels spaced 20 $\mathrm{cm}$, with individual pumping system, and a 310-liter reservoir, kept at a minimum of $95 \%$ of its capacity.

We used cultivar Betty, which is large, plenty of broad and thick leaves which provided adequate head protection, as well as being tolerant to early bolting, 70-day average cycle and an ideal population from 80 to 160 plants per hectare (Horticeres, 2018).

Lettuce seedlings were produced in phenolic foam trays and kept in a nursery for 12 days. After this period, seedlings were transplanted to definite benches, where they remained for 22 days until harvest. The nutrient solution was pumped in a closed circuit, flashing for 15 minutes on and 30 minutes off for 24 hours each day. The authors used PlenanFerti PM1 and PlenanFerti PM2 concentrates (with densities $1.23 \mathrm{~g} /$ $\mathrm{mL}$ ) produced by Plenan, on all phases of the crop. The solution contained the following nutrient contents in $\mathrm{g} / \mathrm{L}$ : $77.65 \mathrm{~N}, 15.95 \mathrm{P}, 75.26 \mathrm{~K}, 23.39 \mathrm{~S}$, $41.60 \mathrm{Ca}, 17.82 \mathrm{Mg}, 0.27 \mathrm{~B}, 0.08 \mathrm{Cu}$, $1.09 \mathrm{Fe}, 0.29 \mathrm{Mn}, 0.05 \mathrm{Mo}, 0.06 \mathrm{Ni}$ and $0.11 \mathrm{Zn}$. Conductivity and $\mathrm{pH}$ were maintained every morning, observing punctual conductivity and replacing the nutrient solution. The nutrient solutions of all treatments were kept at $0.9 \mathrm{dS} / \mathrm{m}$ conductivity in the nursery, at $1.2 \mathrm{dS} / \mathrm{m}$ in the first 10 days after transplanting (DAT) and at $1.6 \mathrm{dS} / \mathrm{m}$ during the rest of the cycle.

Harvest was performed at 22 DAT, when the authors evaluated total, root and shoot fresh masses of 15 lettuce plants. Then, plants were dried in a dryer with forced air circulation at $60^{\circ} \mathrm{C}$ for 72 hours; afterwards, plants were weighed to obtain total, root and shoot fresh masses. After weighing, the plant material was ground using a Willey type mill, passed through 40-mesh sieve; later, it was homogenized and finally, packed in polyethylene bags, properly labelled and stored in a dry chamber until analysis.

In order to determine $\mathrm{N}, \mathrm{P}, \mathrm{K}, \mathrm{Ca}$, $\mathrm{Mg}, \mathrm{S}, \mathrm{B}, \mathrm{Cu}, \mathrm{Fe}, \mathrm{Mn}$, and $\mathrm{Zn}$ contents for shoot, root and leaf diagnosis (newly developed leaves), as recommended by Trani \& Raij (1997), the plant samples were subjected to wet digestion, according to the methodology described by Malavolta et al. (1997).

Nutrient accumulation in shoot and root of plants was calculated based on dry masses and the nutrient contents. Nitrate and ammonia contents were also determined on the dry mass collected from the shoots and roots of lettuce, according to adapted methodology of Silva (2009).

Nutrient use efficiency (EUN) for each treatment was calculated using the following formula: EUN = (total dry mass of plant $)^{2} /$ (total nutrient accumulation in plant); in (g of MS $)^{2} /$ $\mathrm{g}$ of the accumulated nutrient (Siddiqi \& Glass, 1981).

Results were submitted to analysis of variance and, initially, to analysis of polynomial regression, in order to obtain adjustments and equation with low determination coefficient $\left(\mathrm{R}^{2}\right)$, though; considering the practical need to recommend the best flow which considers greater number of evaluations performed considered productive interest of the crop, we compared the averages of treatments (nutrient solution flows) using Tukey test at $5 \%$ probability, using SISVAR program version 5.6 (Ferreira, 2015).

\section{RESULTS AND DISCUSSION}

Lettuce cultivated in a nutrient solution at $1.0 \mathrm{~L} / \mathrm{min}$ flow rate had the highest shoot production on both a fresh 
and dry weight basis (Figure 1), followed by 2.0 and $4.0 \mathrm{~L} / \mathrm{min}$ which did not differ among each other. The least satisfactory result for production of fresh and dry mass of shoot was verified with $0.5 \mathrm{~L} /$ min which was lower in 28 and $32 \%$, respectively, when compared to $1.0 \mathrm{~L} /$ min. The lowest production of fresh and dry mass of shoots was at 2.0 and 4.0 $\mathrm{L} / \mathrm{min}$ flow rates comparing to $1.0 \mathrm{~L} /$ min, showing excessive application of nutrient solution (Figure 1).

NFT method recommends obtaining a nutrient solution depth at the bottom of the cultivation channel measuring no larger than $4 \mathrm{~mm}$ thickness, so that just one third of the root system remains uncovered by the nutrient solution, allowing roots to be oxygenized.

Increasing the flow rate from 2.0 $\mathrm{L} / \mathrm{min}$ to $4.0 \mathrm{~L} / \mathrm{min}$, the depth raised above the second third root, which provoked darkening and necrosis of the structure and also the emergence of pronounced adventitious roots, aiming to compensate the loss of part of root system, nutritional damages were already irreversible, though (Prado \& Cecílio Filho, 2016).

Nevertheless, the increment of the flow proportionally increased the speed of the nutrient solution, which promoted greater friction to the roots acting as physical barriers to the solution trajectory. The effect of increasing friction caused damage to the root system, which contributed to the reduction of the nutrient absorption capacity of the roots, observed by the lowest nutrient accumulation in shoot area (except for $\mathrm{Zn}$ ) in relation to 1.0 $\mathrm{L} / \mathrm{min}$ flow (Figure 2), thus impairing the development of lettuce. This fact could be observed both for the lowest production of fresh and dry mass (Figure 1), and for the lowest root system of lettuce showing signs of low oxygenation (Figure 3 ).

The unsatisfactory result obtained with $0.5 \mathrm{~L} / \mathrm{min}$ flow, both in fresh and dry mass, in the developing of shoot area or root system, shows that there was lower water absorption by the plants. Bandeira et al. (2011) reported that this can be explained by the decrease in leaf water potential, stomatal conductance and $\mathrm{CO}_{2}$ flow, resulting in an adverse impact on accumulations of photoassimilate compounds and as a consequence, reduction in crop production. Water deficit effect causes changes in stomatal responses, osmotic adjustment and important movement of photoassimilates to the roots, metabolic energy consumption and affects crop production anywhere in the plant as well as its commercial quality (Geisenhoff et al., 2016). According to Soares (2007), plants submitted to increasing salinity were less tender, showing more coriaceous leaves: these characteristics were also observed in this study.

In similar study, a flow rate of $0.5 \mathrm{~L} / \mathrm{min}$ also provided lower dry

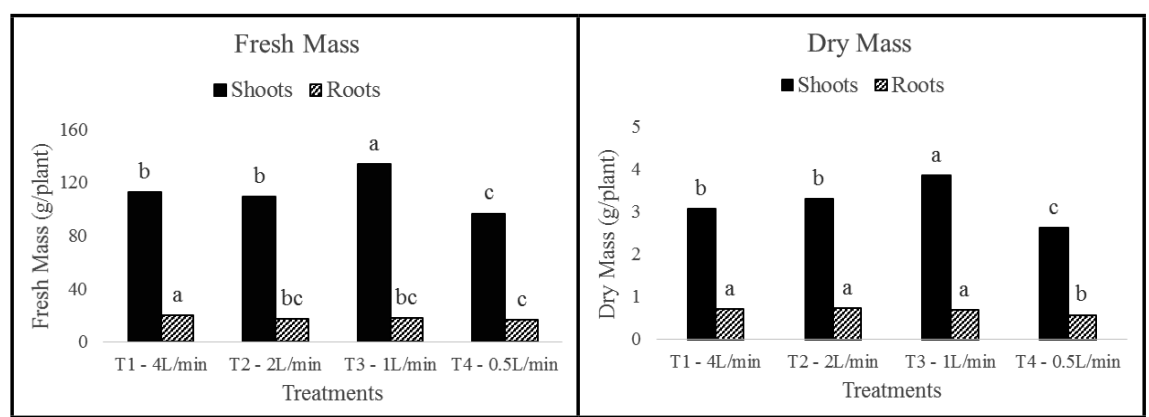

Figure 1. Fresh and dry mass of head lettuce grown in hydroponic system under flow rates of the nutrient solution. Averages followed by same letters did not significantly differ by Tukey test, $\mathrm{p}<0.05$. Aparecida do Taboado, UNESP, 2017.

Table 1. Nutrient contents in the diagnosis leaf of head lettuce grown in hydroponic system under flow rates (4, 2, 1 and $0.5 \mathrm{~L} / \mathrm{min})$ of the nutrient solution. Aparecida do Taboado, UNESP, 2017.

\begin{tabular}{|c|c|c|c|c|c|c|c|c|c|}
\hline \multirow{2}{*}{ Nutrients } & & \multicolumn{2}{|c|}{$4 \mathrm{~L} / \mathrm{min}$} & \multicolumn{2}{|c|}{$2 \mathrm{~L} / \mathrm{min}$} & \multicolumn{2}{|c|}{$1 \mathrm{~L} / \mathrm{min}$} & \multicolumn{2}{|c|}{$0.5 \mathrm{~L} / \mathrm{min}$} \\
\hline & & Content & $\%$ & Content & $\%$ & Content & $\%$ & Content & $\%$ \\
\hline $\mathrm{N}$ & \multirow{6}{*}{ 客 } & $39.43 \mathrm{~A}$ & $43 \%$ & $43.80 \mathrm{~A}$ & $45 \%$ & $42.0 \mathrm{~A}$ & $46 \%$ & $43.43 \mathrm{~A}$ & $42 \%$ \\
\hline $\mathrm{P}$ & & $7.43 \mathrm{H}$ & $8 \%$ & $6.73 \mathrm{~A}$ & $7 \%$ & $7.53 \mathrm{H}$ & $8 \%$ & $10.20 \mathrm{H}$ & $10 \%$ \\
\hline $\mathrm{K}$ & & $20.37 \mathrm{~L}$ & $-22 \%$ & $24.57 \mathrm{~L}$ & $-25 \%$ & $21.70 \mathrm{~L}$ & $-24 \%$ & $20.97 \mathrm{~L}$ & $-20 \%$ \\
\hline $\mathrm{Ca}$ & & $15.17 \mathrm{~A}$ & $17 \%$ & $12.80 \mathrm{~L}$ & $-13 \%$ & $11.70 \mathrm{~L}$ & $-13 \%$ & $18.43 \mathrm{~A}$ & $18 \%$ \\
\hline $\mathrm{Mg}$ & & $4.77 \mathrm{~A}$ & $5 \%$ & $4.93 \mathrm{~A}$ & $5 \%$ & $5.20 \mathrm{~A}$ & $6 \%$ & $5.90 \mathrm{~A}$ & $6 \%$ \\
\hline $\mathrm{S}$ & & $3.53 \mathrm{H}$ & $4 \%$ & $3.13 \mathrm{H}$ & $3 \%$ & $2.97 \mathrm{H}$ & $3 \%$ & $3.83 \mathrm{H}$ & $4 \%$ \\
\hline B & \multirow{5}{*}{ 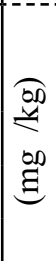 } & $77.33 \mathrm{H}$ & $0.08 \%$ & $62.67 \mathrm{H}$ & $0.06 \%$ & $55.00 \mathrm{~A}$ & $0.06 \%$ & $102.33 \mathrm{H}$ & $0.10 \%$ \\
\hline $\mathrm{Cu}$ & & $39.00 \mathrm{H}$ & $0.04 \%$ & $24.67 \mathrm{H}$ & $0.03 \%$ & $15.33 \mathrm{~A}$ & $0.02 \%$ & $40.67 \mathrm{H}$ & $0.04 \%$ \\
\hline $\mathrm{Fe}$ & & $242.67 \mathrm{H}$ & $0.27 \%$ & $164.67 \mathrm{H}$ & $0.17 \%$ & $149.67 \mathrm{~A}$ & $0.16 \%$ & $237.33 \mathrm{H}$ & $0.23 \%$ \\
\hline $\mathrm{Mn}$ & & $176.33 \mathrm{H}$ & $0.19 \%$ & $124.67 \mathrm{~A}$ & $0.13 \%$ & $134.67 \mathrm{~A}$ & $0.15 \%$ & $182.67 \mathrm{H}$ & $0.18 \%$ \\
\hline $\mathrm{Zn}$ & & $244.67 \mathrm{H}$ & $0.27 \%$ & $134.67 \mathrm{H}$ & $0.14 \%$ & $117.67 \mathrm{H}$ & $0.13 \%$ & $184.33 \mathrm{H}$ & $0.18 \%$ \\
\hline
\end{tabular}

Nutrients contents in the diagnosis lettuce leaf, based on data obtained by Trani \& Raij (1997), indicated as high (H), adequate (A) and low (L). Values in \% show an increase or reduction in relation to the average content of each nutrient. ${ }^{1}$ Flow rates submitted to a rectangular PVC duct, with intermittence of 15 minutes and intervals of 30 minutes, seven-meter length and slope of $10 \%$. 


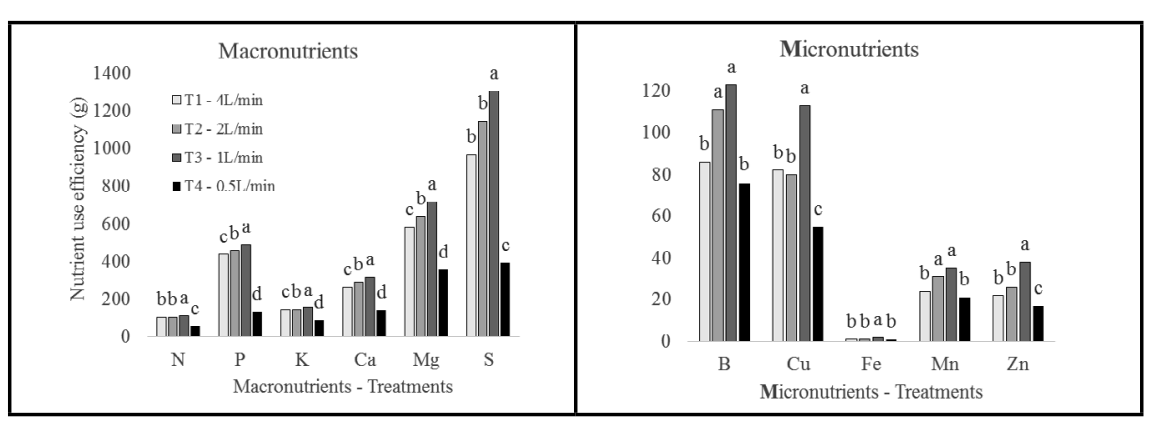

Figure 2. Nutrient use efficiency of head lettuce grown in hydroponic system under flow rates of the nutrient solution. Aparecida do Taboado, UNESP, 2017.

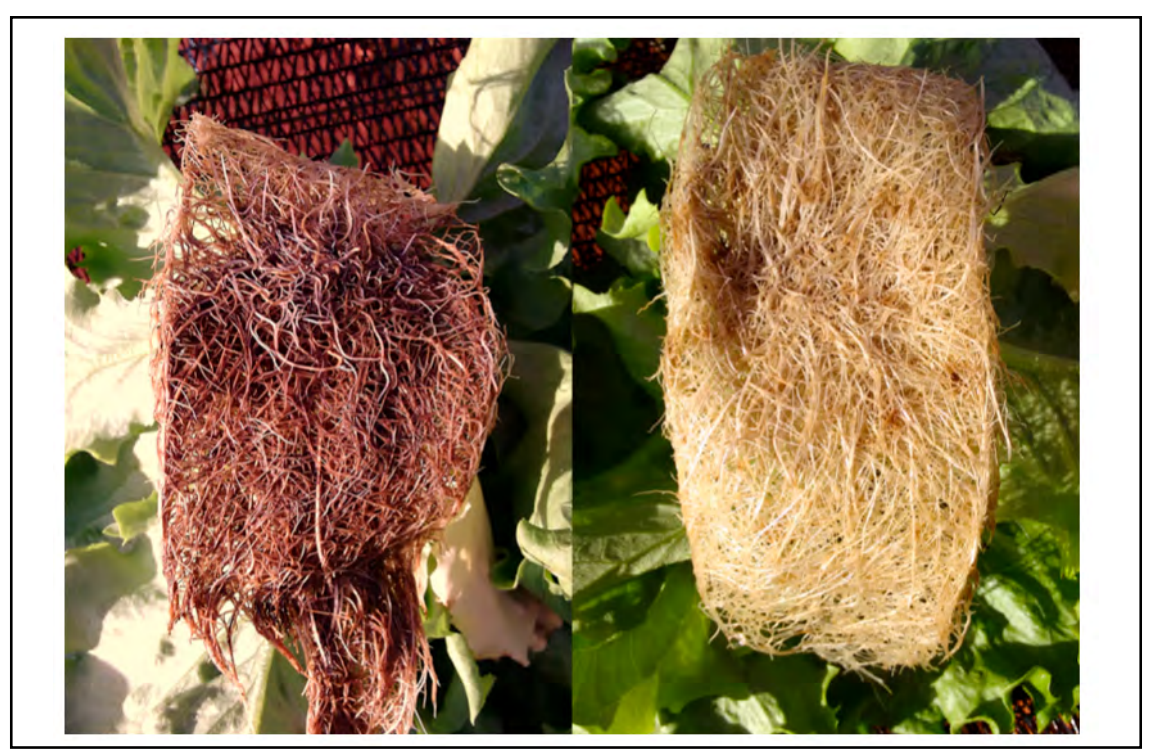

Figure 3. Lettuce root system showing signs of stress caused by low oxygenation (left), related to a nutrient solution at $4.0 \mathrm{~L} / \mathrm{min}$ flow rate and well-developed root system with adequate oxygen supply (right), nutrient solution at $1.0 \mathrm{~L} / \mathrm{min}$ flow rate source: Dalastra (2017)\}. Aparecida do Taboado, UNESP, 2017.

mass production than the other rates in experiments carried out in Parana (Santos et al., 2011) and Rio de Janeiro (Genuncio et al., 2012). We highlight that temperature, relative humidity and more intense solar radiation where the experiment was conducted also contribute for water stress, causing even more damage to the plants grown at this flow rate.

In relation to lettuce root system, for fresh mass, the highest development was obtained at $4.0 \mathrm{~L} / \mathrm{min}$, followed by 2.0 and $1.0 \mathrm{~L} / \mathrm{min}$ which did not differ from $0.5 \mathrm{~L} / \mathrm{min}$, which obtained the lowest value for root fresh mass (Figure 1). The treatment with $4.0 \mathrm{~L} / \mathrm{min}$ was the only one to provide different behavior between dry and fresh mass, showing an increase in fresh mass as opposed to dry mass (Figure 1). The expression of this behavior may be associated with the beneficial effect of heat dissipation inside the cultivation channel, given the high volume of current solution in this treatment (Casaroli et al., 2003). Thus, the plants absorbed more water, but as they absorbed less $\mathrm{CO}_{2}$, there was less accumulation of lettuce dry mass in this treatment.

Evaluating nutrient contents in diagnose leaf based on sufficiency ranges proposed by Trani \& Raij (1997), the authors verified that, for all treatments, leaf nutrient contents were adequate or high, except for $\mathrm{K}$ which was deficient (Table 1). We also highlight that the flow rates 1.0 and 2.0 $\mathrm{L} /$ min provided $\mathrm{Ca}$ contents in leaves lower than the one recommended by the mentioned authors. However, no $\mathrm{K}$ and $\mathrm{Ca}$ deficiency symptoms were observed, which characterizes a moderate deficiency (hidden hunger) or even a smaller demand of this lettuce cultivar in relation to these exchangeable bases. Petrazzini et al. (2014), evaluating simple omissions (K, $\mathrm{Ca}, \mathrm{B}, \mathrm{Zn}$ ) and combined omissions ( $\mathrm{Ca}$ and $\mathrm{B}$; $\mathrm{K}$ and $\mathrm{Zn}$; $\mathrm{B}$ and $\mathrm{Zn}$ ) of nutrients and a control (with all nutrients) in head lettuce Rider Plus, concluded that under $\mathrm{Ca}$ omission, the plants showed chlorosis on younger leaf margins, and $\mathrm{K}$ was the nutrient which the most restricted the production of fresh mass, shoot dry mass and root dry mass. Paulus et al. (2012), in hydroponic cultivation system with saline water, did not verify nutritional deficiency symptoms in lettuce plants cv. Verônica and Pira Roxa.

For shoot nutrient contents (Table 2), the authors noticed higher contents of $\mathrm{P}$, $\mathrm{Ca}, \mathrm{Mg}, \mathrm{Mn}$ and $\mathrm{Zn}$ at the lowest flow rate $(0.5 \mathrm{~L} / \mathrm{min})$, due to concentration effect, since, in this treatment, we could notice lower dry matter accumulation. We highlight that this flow rate $(0.5 \mathrm{~L} /$ min) provided higher nitrate content and lower ammonium content when compared to the others.

For root nutrient contents (Table 2), the lowest flow rate provided highest contents of $\mathrm{P}, \mathrm{S}, \mathrm{Fe}$ and $\mathrm{Cu}$, whereas at the highest flow rate $(4.0 \mathrm{~L} / \mathrm{min})$, we verified higher $B$ content in the root. In relation to other nutrient contents, nitrate and ammonium, no difference between treatments was noticed.

However, when nutrient contents in lettuce shoot area were considered, we noticed that the flow rate of $1.0 \mathrm{~L} /$ min provided higher nutrient contents (except for $\mathrm{Zn}$ ), ratifying the best performance for fresh and dry mass production in this treatment (Table 2). $\mathrm{Zn}$ content may have been lower due to ion antagonism since non-competitive inhibition presented between $\mathrm{Zn}$ and P (Moreira et al., 2001). The flows of 4.0 and $2.0 \mathrm{~L} / \mathrm{min}$ provided moderate nutrient accumulation, and the flow rate of $0.5 \mathrm{~L} / \mathrm{min}$ provided lower accumulated amounts of most nutrients, and similar accumulation could be verified at the flow rate of 4.0 and 2.0 $\mathrm{L} / \mathrm{min}$ for some nutrients. These results corroborate the conclusion that nutrient accumulation shows a close correlation with crop production in relation to 
nutrient contents.

In root system, the situation is opposite; at the flow rate of $0.5 \mathrm{~L} / \mathrm{min}$, we noticed higher nutrient accumulation, except B and Mn (Table 2), whereas in the treatment with a flow rate of 1.0 $\mathrm{L} / \mathrm{min}$, we noticed lower accumulated nutrients in the roots. This is due to higher transport efficiencies (Dalastra, 2017) and due to use of all nutrients verified at a flow rate of $1.0 \mathrm{~L} / \mathrm{min}$ (Figure 2).

Nitrate content in shoot was high when a lower flow rate $(0.5 \mathrm{~L} / \mathrm{min})$ was used, reaching up to $3.5 \mathrm{~g} / \mathrm{kg}$. In the other treatments nitrate content was lower than $0.85 \mathrm{~g} / \mathrm{kg}$ (Table 2). Lower nitrate contents were obtained by Cavarianni et al. (2000), evaluating lettuce cultivars showing contents from 1.545 to $1.963 \mathrm{~g} / \mathrm{kg}$ for loose leaf type lettuce, from 1.242 to $1.536 \mathrm{~g} / \mathrm{kg}$ for crispy head lettuce and from 1.030 to $1.965 \mathrm{~g} / \mathrm{kg}$ for head lettuce. We highlight that nitrate contents, except the ones obtained at the lowest flow rate, are quite lower than the standard set by European legislation, from 3.50 to $4.55 \mathrm{~g} / \mathrm{kg}$ for fresh mass (Faquin \& Andrade, 2004). Pôrto et al. (2012) verified that the maximum content of nitrate on leaves is below the risk limit for human health, and that the increase of $\mathrm{N}$ availability in the nutrient solutions results in a linear increase of nitrate contents in different parts of lettuce cv. Elba.

Nitrogen, constituent of amino acids, proteins, enzymes, coenzymes and nucleotides (Malavolta et al., 1997) is provided for the plant in hydroponics system in the form of ammonium ion and nitrate. However, nitrate is reduced to nitrite in the plant cell cytoplasm and then, nitrite is converted to ammonium in chloroplasts during photosynthetic process (Faquin \& Andrade, 2004). Nevertheless, under water stress, even when it is moderate, the plant shows a

Table 2. Content and accumulation of nutrients in shoots and roots of head lettuce grown in hydroponic system under flow rates $(4,2,1$ and $0.5 \mathrm{~L} / \mathrm{min}$ ) of the nutrient solution. Aparecida do Taboado, UNESP, 2017.

\begin{tabular}{|c|c|c|c|c|c|c|c|c|c|c|c|c|c|c|c|}
\hline \multirow{3}{*}{$\begin{array}{l}\text { Nutrients } \\
\mathrm{N}\end{array}$} & \multirow{2}{*}{\multicolumn{2}{|c|}{$4 \mathrm{~L} / \mathrm{min}$}} & \multicolumn{2}{|c|}{$2 \mathrm{~L} / \mathrm{min}$} & \multirow{2}{*}{\multicolumn{2}{|c|}{$\frac{1 \mathrm{~L} / \mathrm{min}}{\operatorname{hoots}(\mathrm{g} / \mathrm{kg})}$}} & \multicolumn{2}{|c|}{$0.5 \mathrm{~L} / \mathrm{min}$} & $4 \mathrm{~L} / \mathrm{mi}$ & & \multicolumn{2}{|c|}{$2 \mathrm{~L} / \mathrm{min}$} & $1 \mathrm{~L} / \mathrm{min}$ & \multicolumn{2}{|c|}{$0.5 \mathrm{~L} / \mathrm{min}$} \\
\hline & & & \multicolumn{4}{|c|}{ Content in shoots $(\mathrm{g} / \mathrm{kg})$} & & & \multicolumn{7}{|c|}{ Accumulation in shoots (g/plant) } \\
\hline & 38.40 & $\mathrm{a}$ & 40.57 & $\bar{a}$ & 39.67 & $\overline{\mathrm{a}}$ & 42.07 & $\mathrm{a}$ & 0.110 & $\mathrm{c}$ & 0.130 & $\mathrm{~b}$ & $0.160 \mathrm{a}$ & 0.100 & $\mathrm{c}$ \\
\hline $\mathrm{NO}_{3}^{-}$ & 0.642 & $\mathrm{~b}$ & 0.858 & $\mathrm{~b}$ & 0.805 & $\mathrm{~b}$ & 3.500 & $\mathrm{a}$ & 0.002 & $\mathrm{~b}$ & 0.003 & $\mathrm{~b}$ & $0.009 \mathrm{a}$ & 0.009 & $\mathrm{a}$ \\
\hline $\mathbf{N H}_{4}^{+}$ & 2.193 & $\mathrm{a}$ & 2.362 & $\mathrm{a}$ & 2.333 & $\mathrm{a}$ & 1.925 & $\mathrm{~b}$ & 0.007 & $\mathrm{a}$ & 0.008 & $\mathrm{a}$ & $0.009 \mathrm{a}$ & 0.005 & $\mathrm{~b}$ \\
\hline $\mathbf{P}$ & 8.03 & $\mathrm{~b}$ & 7.43 & $\mathrm{~b}$ & 8.10 & $\mathrm{~b}$ & 10.83 & $\mathrm{a}$ & 0.020 & $\mathrm{~b}$ & 0.020 & $\mathrm{~b}$ & $0.030 \mathrm{a}$ & 0.020 & $\mathrm{~b}$ \\
\hline $\mathbf{K}$ & 30.37 & $\mathrm{a}$ & 31.57 & $\mathrm{a}$ & 31.40 & $\mathrm{a}$ & 28.20 & $\mathrm{a}$ & 0.090 & $\mathrm{c}$ & 0.100 & $\mathrm{~b}$ & $0.120 \mathrm{a}$ & 0.060 & $\mathrm{~d}$ \\
\hline $\mathbf{C a}$ & 16.60 & $\mathrm{~b}$ & 15.80 & $\mathrm{~b}$ & 15.23 & $\mathrm{~b}$ & 21.80 & $\mathrm{a}$ & 0.050 & $\mathrm{~b}$ & 0.050 & $\mathrm{~b}$ & $0.060 \mathrm{a}$ & 0.050 & $\mathrm{~b}$ \\
\hline Mg & 7.80 & $\mathrm{~b}$ & 7.57 & $\mathrm{~b}$ & 6.93 & $\mathrm{~b}$ & 9.63 & $\mathrm{a}$ & 0.020 & $\mathrm{~b}$ & 0.020 & $\mathrm{~b}$ & $0.030 \mathrm{a}$ & 0.020 & $\mathrm{~b}$ \\
\hline \multirow[t]{2}{*}{$\mathbf{S}$} & 3.30 & $\mathrm{a}$ & 2.93 & $\mathrm{a}$ & 2.80 & $\mathrm{a}$ & 3.03 & $\mathrm{a}$ & 0.010 & $\mathrm{~b}$ & 0.010 & $\mathrm{~b}$ & $0.010 \quad \mathrm{a}$ & 0.010 & $\mathrm{c}$ \\
\hline & \multicolumn{8}{|c|}{ Content in shoots $(\mathrm{mg} / \mathrm{kg})$} & \multicolumn{7}{|c|}{ Accumulation in shoots (mg/plant) } \\
\hline $\mathbf{B}$ & 37.33 & $\mathrm{a}$ & 34.33 & $\mathrm{a}$ & 34.00 & $\mathrm{a}$ & 42.00 & $\mathrm{a}$ & 0.11 & $\mathrm{~b}$ & 0.11 & $\mathrm{~b}$ & 0.13 a & 0.10 & $\mathrm{~b}$ \\
\hline $\mathbf{C u}$ & 18.00 & $\mathrm{a}$ & 15.67 & $\mathrm{a}$ & 13.67 & $\mathrm{a}$ & 22.00 & $\mathrm{a}$ & 0.05 & $\mathrm{a}$ & 0.05 & $\mathrm{a}$ & $0.05 \mathrm{a}$ & 0.05 & $\mathrm{a}$ \\
\hline $\mathbf{F e}$ & 296.33 & a & 233.33 & $\mathrm{a}$ & 240.67 & a & 287.00 & $\mathrm{a}$ & 0.86 & a & 0.75 & $\mathrm{~b}$ & 0.93 a & 0.66 & $\mathrm{~b}$ \\
\hline Mn & 187.00 & $\mathrm{~b}$ & 148.00 & $\mathrm{bc}$ & 137.67 & $\mathrm{c}$ & 191.67 & $\mathrm{a}$ & 0.54 & $\mathrm{a}$ & 0.47 & $\mathrm{~b}$ & 0.54 a & 0.44 & $\mathrm{~b}$ \\
\hline \multirow[t]{2}{*}{ Zn } & 188.00 & $\mathrm{a}$ & 162.00 & $\mathrm{ab}$ & 118.33 & $\mathrm{~b}$ & 217.67 & $\mathrm{a}$ & 0.55 & $\mathrm{a}$ & 0.52 & $\mathrm{ab}$ & $0.47 \quad \mathrm{~b}$ & 0.50 & $\mathrm{ab}$ \\
\hline & \multicolumn{8}{|c|}{ Content in roots $(\mathrm{g} / \mathrm{kg})$} & \multicolumn{7}{|c|}{ Accumulation in roots (g/plant) } \\
\hline $\mathbf{N}$ & 36.67 & $\mathrm{a}$ & 37.93 & $\mathrm{a}$ & 37.60 & $\mathrm{a}$ & 33.70 & $\mathrm{a}$ & 0.026 & $\mathrm{~b}$ & 0.028 & $\mathrm{~b}$ & $0.026 \mathrm{~b}$ & 0.083 & $\mathrm{a}$ \\
\hline $\mathbf{P}$ & 13.20 & $\mathrm{c}$ & 16.27 & $\mathrm{~b}$ & 15.07 & $\mathrm{~b}$ & 22.30 & $\mathrm{a}$ & 0.009 & $\mathrm{~b}$ & 0.012 & $\mathrm{~b}$ & $0.010 \mathrm{~b}$ & 0.052 & $\mathrm{a}$ \\
\hline $\mathbf{K}$ & 15.40 & $\mathrm{a}$ & 14.37 & $\mathrm{a}$ & 15.17 & a & 19.43 & $\mathrm{a}$ & 0.011 & $\mathrm{~b}$ & 0.011 & $\mathrm{~b}$ & $0.011 \mathrm{~b}$ & 0.050 & $\mathrm{a}$ \\
\hline $\mathbf{C a}$ & 8.63 & $\mathrm{a}$ & 7.90 & a & 8.03 & $\mathrm{a}$ & 8.97 & $\mathrm{a}$ & 0.006 & $\mathrm{~b}$ & 0.006 & $\mathrm{~b}$ & $0.006 \mathrm{~b}$ & 0.022 & $\mathrm{a}$ \\
\hline Mg & 2.83 & $\mathrm{a}$ & 2.10 & $\mathrm{a}$ & 2.50 & $\mathrm{a}$ & 2.70 & $\mathrm{a}$ & 0.002 & $\mathrm{~b}$ & 0.002 & $\mathrm{~b}$ & $0.002 \mathrm{~b}$ & 0.007 & $\mathrm{a}$ \\
\hline $\mathbf{S}$ & 7.47 & $\mathrm{~b}$ & 6.57 & $\mathrm{~b}$ & 7.07 & $\mathrm{~b}$ & 9.23 & $\mathrm{a}$ & 0.005 & $\mathrm{~b}$ & 0.005 & $\mathrm{~b}$ & $0.005 \mathrm{~b}$ & 0.019 & $\mathrm{a}$ \\
\hline \multicolumn{9}{|c|}{ Content in roots $(\mathrm{mg} / \mathrm{kg})$} & \multicolumn{7}{|c|}{ Accumulation in roots (mg/plant) } \\
\hline $\mathbf{B}$ & 84.00 & $\overline{\mathrm{a}}$ & 50.33 & $\mathrm{~b}$ & 54.00 & $\bar{b}$ & 63.00 & $\mathrm{~b}$ & 0.059 & $\bar{a}$ & 0.037 & $\mathrm{~b}$ & $0.038 \mathrm{~b}$ & 0.039 & $\mathrm{~b}$ \\
\hline $\mathrm{Cu}$ & 176.33 & $\mathrm{c}$ & 207.00 & $a b$ & 186.67 & $\mathrm{bc}$ & 222.00 & $\mathrm{a}$ & 0.124 & $\mathrm{~b}$ & 0.154 & $\mathrm{a}$ & $0.130 \mathrm{~b}$ & 0.137 & $a b$ \\
\hline $\mathbf{F e}$ & 127.94 & $\mathrm{c}$ & 152.11 & $\mathrm{~b}$ & 115.31 & $\mathrm{c}$ & 245.23 & $\mathrm{a}$ & 8.961 & $\mathrm{c}$ & 11.29 & $\mathrm{~b}$ & $7.957 \mathrm{c}$ & 15.070 & $\mathrm{a}$ \\
\hline Mn & 91.33 & $\mathrm{a}$ & 75.33 & $\mathrm{a}$ & 73.00 & $\mathrm{a}$ & 76.67 & $\mathrm{a}$ & 0.064 & $\mathrm{a}$ & 0.056 & $\mathrm{~b}$ & $0.051 \mathrm{bc}$ & 0.047 & $\mathrm{c}$ \\
\hline $\mathbf{Z n}$ & 157.67 & $\mathrm{a}$ & 140.00 & $\mathrm{a}$ & 120.33 & $\mathrm{a}$ & 174.67 & $\mathrm{a}$ & 0.110 & $\mathrm{a}$ & 0.104 & $\mathrm{a}$ & $0.084 \quad \mathrm{~b}$ & 0.107 & $\mathrm{a}$ \\
\hline
\end{tabular}

Averages followed by same letters on lines did not significantly differ from each other by Tukey's test, $p<0.05$. 
decrease in photosynthetic rate (Lawlor \& Tezara, 2009), favoring nitrate accumulation in tissues. In other studies, nitrate behavior in lettuce tissues tended to increase as it becames different from $1 \mathrm{~L} / \mathrm{min}$ flow rate, higher or lower levels (Ohse et al., 2009; Aprígio et al., 2012), corroborating somehow the obtained results.

The treatments evaluated in this study showed the following order of macronutrients extraction: $\mathrm{N}>\mathrm{K}>\mathrm{Ca}>\mathrm{P}>\mathrm{Mg}>\mathrm{S}$ (Table 2), similar to the reported: adequate for high lettuce productivity (Faquin et al., 1996). For micronutrients, at flow rates of 2.0 and $0.5 \mathrm{~L} / \mathrm{min}$, the authors verified that extraction order was $\mathrm{Fe}>\mathrm{Zn}>\mathrm{Mn}>\mathrm{B}>\mathrm{Cu}$, similar to the one described by Faquin et al. (1996); however, the flow rate of $4.0 \mathrm{~L} / \mathrm{min}$ showed alternation between the order of $\mathrm{Fe}$ and $\mathrm{Zn}$ and the flow rate of $1.0 \mathrm{~L} / \mathrm{min}$ reversed the order of $\mathrm{Mn}$ and $\mathrm{Zn}$.

Given the above, we could conclude that the flow rate in hydroponics systems in order to produce head lettuce, alters the crop growth and development. The highest head lettuce production is obtained in a nutrient solution at $1.0 \mathrm{~L} /$ min flow rate.

\section{REFERENCES}

ABCSEM - Associação brasileira do comercio de sementes e mudas. 2017, June 26. Dados do setor. Available at: http://www.abcsem.com. br/dados-do-setor

APRÍGIO, A; REZENDE, R; FREITAS, PSL; COSTA, AR; SOUZA, RS. 2012. Teor de nitrato em alface hidropônica em função de vazões e períodos de pós-colheita. Revista Brasileira de Engenharia Agrícola e Ambiental 16: 946-951.

BANDEIRA, GRL; PINTO, HCS; MAGALHÃES, PS; ARAGÃO, CA; QUEIROZ, SOP; SOUZA, ER; SEIDO, SL. 2011. Manejo de irrigação para cultivo de alface em ambiente protegido. Horticultura Brasileira 29: 237 241.

CARMELLO, QAC. 1996. Cultivo hidropônico de plantas. Piracicaba: ESALQ-USP, 43p.

CAVARIANNI, RL; CAZETTA, JO; MAY, A; BARBOSA, JC; CECÍLIO FILHO, AB. 2000. Acúmulo de nitrato em cultivares de alface, cultivada na primavera, em função do ambiente de cultivo. Horticultura Brasileira 18: 324-325.

CASAROLI, D; FAGAN, EB; SANTOS, OS; BONNECARRÈRE, RAG; NOGUEIRA
FILHO, H. 2003. Desempenho de onze cultivares de alface em duas formas diferentes de canais de cultivo, no sistema hidropônico. Revista da faculdade de Zootecnia, Veterinária e Agronomia 10: 25-33.

CONAB - Companhia Nacional de Abastecimento. 2017, June 26. Programa brasileiro de modernização do mercado hortigranjeiro. Available at: http://www3.ceasa.gov.br/ prohortweb

COOPER, A. 1996. The ABC of NFT. Australia: Casper Publications, 171p.

DALASTRA, C. 2017. Nutrição e produção de alface americana em função da vazão, periodicidade de exposição e condutividade elétrica da solução nutritiva em sistema hidropônico. Ilha Solteira: FEIS-UNESP. 98p. (Ph.D. thesis).

FAQUIN, V; ANDRADE, AT. 2004. Nutrição mineral e diagnose do estado nutricional de hortaliças. Lavras: UFLA/FAEPE, 88p.

FAQUIN, V; FURLANI NETO, AE; VILELA, LAA. 1996. Produção de alface em hidroponia. Lavras: UFLA/FAEPE, 50p.

FAQUIN, V; FURLANI, PR. 1999. Cultivo de hortaliças em hidroponia em ambiente protegido. Informe Agropecuário 20: 99-104.

FERREIRA, DF. 2015. Sisvar. Versão 5.6. Lavras: UFLA/DEX, 2015. Available at: http://www. dex.ufla.br/ danielff/programas/sisvar.html.

GEISENHOFF, LO; PEREIRA, GM; LIMA JUNIOR, JA; SILVA, ALP; AVIZ, WLCD. 2016. Greenhouse crisphead lettuce grown with mulching and under different soil water tensions. Engenharia Agricola 36: 46-54.

GENUNCIO, GC; GOMES, M; FERRARI, AC; MAJEROWICZ, N; ZONTA, E. 2012. Hydroponic lettuce production in different concentrations and flow rates of nutrient solution. Horticultura Brasileira 30: 526-530.

GUALBERTO, R; OLIVEIRA, PSR; GUIMARÃES, AM. 2009. Adaptabilidade e estabilidade fenotípica de cultivares de alface do grupo crespa em cultivo hidropônico. Horticultura Brasileira 27: 7-11.

HELBEL JÚNIOR, C. 2004. Produção de alface hidropônica em função da composição da solução nutritiva e vazões Maringá: Universidade Estadual de Maringá. 92p. (M.Sc. thesis).

HELBEL JÚNIOR, C; REZENDE, R; FREITAS, PSL; GONÇALVES, ACA; FRIZZONE, JA. 2008. Influência da condutividade elétrica, concentração iônica e vazão de soluções nutritivas na produção de alface hidropônica. Ciência e Agrotecnologia, 32: 1142-1147.

HORTICERES. 2018. Alface Betty. Available at: http://www.horticeres.com.br/produtos/ folhosas/alface/alface-betty. Accessed October $10,2018$.

LAWLOR, DW; TEZARA, W. 2009. Causes of decreased photosynthetic rate and metabolic capacity in water-deficient leaf cells: a critical evaluation of mechanisms and integration of processes. Annals of Botany 103: 561-579.

LONDERO, FAA; AITA, A. 2000. Comercialização de alface hidropônica. In: SANTOS, O (ed). Hidroponia da Alface. Santa Maria: UFSM, p.145-152.
MALAVOLTA, E; VITTI, GC; OLIVEIRA, SA. 1997. Avaliação do estado nutricional das plantas: princípios e aplicações. 2. ed. Piracicaba: Potafos, 319p.

MOREIRA, MA; FONTES, PCR; CAMARGO, MI. 2001. Interação zinco e fósforo em solução nutritiva influenciando o crescimento e a produtividade da alface. Pesquisa Agropecuária Brasileira 36: 903-909.

OHSE, S; RAMOS, DMR; CARVALHO, SMD; FETT, R; OLIVEIRA, JLB. 2009. Composição centesimal e teor de nitrato em cinco cultivares de alface produzidas sob cultivo hidropônico. Bragantia 68: 407-414.

PAULUS, D; DOURADO NETO, D; PAULUS, E. 2012. Análise sensorial, teores de nitrato e de nutrientes de alface cultivada em hidroponia sob águas salinas. Horticultura Brasileira 30: 18-25.

PETRAZZINI, LL; SOUZA, GA; RODAS, CL; EMRICH, EB; CARVALHO, JG; SOUZA, RJ. 2014. Nutritional deficiency in crisphead lettuce grown in hydroponics. Horticultura Brasileira 32: 310-313.

PÔRTO, MLA; ALVES, JC, SOUZA, AP; ARAÚJO, RC; ARRUDA, JA; TOMPSON JÚNIOR, UA. 2012. Doses de nitrogênio no acúmulo de nitrato e na produção da alface em hidroponia. Horticultura Brasileira 30: 539-543.

PRADO, RM; CECÍLIO FILHO, AB. Nutrição e adubação de hortaliças. 2016. Jaboticabal: UNESP. 600p.

RODRIGUES, LRF. 2002. Técnicas de cultivo hidropônico e de controle ambiental no manejo de pragas, doenças e nutrição vegetal em ambiente protegido. Jaboticabal: UNESP, $762 \mathrm{p}$.

SANTOS, OS. 2000. Conceito, histórico e vantagens da hidroponia. In: SANTOS, O (ed). Hidroponia da alface. Santa Maria: UFSM. p.5-9.

SANTOS, RF; FURTADO, LF; BASSEGIO, D; SECCO, D; SOUZA, SNM; FRIGO, EP. 2011. Relação entre as vazões de aplicação de solução nutritiva em cultivo de alface hidropônica. Revista Cultivando o Saber 4: 204-216.

SILVA, FC. 2009. Manual de análises químicas de solos, plantas e fertilizantes. 2.ed. BrasíliaDF: Embrapa Informação Tecnológica; Rio de Janeiro: Embrapa Solos. 627.

SIDDIQI, MY; GLASS, ADM. 1981. Utilization index: a modified approach to the estimation and comparison of nutrient utilization efficiency in plants. Journal of Plant Nutrition 4: 289-302.

SOARES, TM. 2007. Utilização de águas salobras no cultivo da alface em sistema hidropônico NFT com alternativa agricola condizente ao semi-árido brasileiro. Piracicaba: USPESALQ. 267p. (Ph.D. thesis).

STAFF, H. 1998. Hidroponia. $2^{\text {nd }}$ ed. Cuiabá: SEBRAE-MT. 101p. (Coleção Agroindústria; V. 11).

TRANI, P; RAIJ, B. 1997. Hortaliças. In: Recomendações de adubação e calagem para o estado de São Paulo. Campinas: IAC. p.157164. (Boletim Técnico, 100). 